\title{
The Religious Guidance Efforts to Prevent Student Moral Decadence
}

\author{
Musnar Indra Daulay 1, Pandu Adi Cakranegara 2, Fauzi Aldina 3, Supeno 4, \\ Achmad Syarifudin5
}

DOI: $10.35445 /$ alishlah.v13i3.1531

Article Info

Keywords:

Development, Religious

Affairs, Religious

Extracurricular, Moral

\section{Abstract}

This study aims to analyze efforts to prevent moral decadence in students through religious development. The research method used is qualitative research with a phenomenological approach. The objects in this research are teachers and their activities, programs, and extracurricular activities. Informants in this study were principals, vice principals, subject teachers, and activity supervisors. Data were collected through observation and in-depth interviews. Data were analyzed by data reduction, data presentation, and concluding. This study concludes that there are three strategies carried out by the school in an effort to prevent the occurrence of adolescent moral decadence, namely teacher exemplary, religious programs, and religious extracurriculars.

\begin{abstract}
Abstrak
Penelitian ini bertujuan untuk menganalisis upaya mencegah dekadansi moral pada siswa melalui pembinaan keberagamaan. Metode penelitian yang digunakan adalah penelitian kualitatif dengan pendekatan fenemonologis. Objek dalam penelitian ini adalah guru dan aktivitasnya, program, dan kegiatan ekstrakurikuler. Informan dalam penelitian ini adalah kepala sekolah, wakil kepala sekolah, guru mata pelajaran, dan guru pembina kegiatan. Data dikumpulkan melalui observasi dan wawancara mendalam. Data dianalisis dengan reduksi data, penyajian data, dan penarikan kesimpulan. Penelitian ini menyimpulkan bahwa ada tiga strategi yang dilakukan oleh pihak sekolah dalam upaya mencegah terjadinya dekadensi moral remaja yaitu keteladanan guru, program keagamaan, dan ekstrakurikuler keagamaan.
\end{abstract}

\footnotetext{
${ }^{1}$ Universitas Pahlawan Tuanku Tambusai, Indonesia

Email: musnarindradaulay@gmail.com

2 Universitas Presiden, Indonesia

Email: pandu.cakranegara@president.ac.id

3 Universitas Jabal Ghafur, Indonesia

Email: fauzialdina@unigha.ac.id

4 Universitas Batanghari Jambi, Indonesia

Email: supeno@unbari.ac.id

5 UIN Raden Fatah Palembang, Indonesia

Email: achmadsyarifudin73@radenfatah.ac.id
} 


\section{INTRODUCTION}

Moral decadence was a moral decline in individuals caused by several factors, including environmental (external) and individual (internal) factors (Daradjat, 2000; Sarwono, 1997). Moral decadence will negatively affect teenagers and others, one of which was disturbing the comfort and tranquillity in social life. In contrast, teenagers were candidates for the next baton in society (Jannah, 2021). The behaviours that show moral decadence often occur include adultery, theft, free use of narcotics and illegal drugs, pornography, crime, free sex, disobedience of children to parents, abortion among teenagers, and others. It had become a very concerning social problem and had not been completely resolved (Budiningsih, 2004). This behaviour was increasing day by day, making teachers and parents worried.

Moral decadence was currently increasingly worrying, and its cases were increasing in almost every big city in Indonesia, such as Jakarta, Semarang, Surabaya, Batam, Medan, Pekanbaru, Palembang, and other cities. Even during the Covid-19 pandemic, juvenile delinquency still occurred because the space to channel youth's energy and creativity was reduced (Tashandra, 2021). If this problem was not addressed quickly, it was possible that a nation would be damaged and civilization would decline. Morality was the main element in building society to achieve an orderly, safe, peaceful, and prosperous society (Megawangi, 2004). This phenomenon had shocked policymakers and worried about adolescents' moral change, leading to demoralization, which was an attitude that had forgotten religious values and only prioritized Western values and culture or lexically, demoralization meant moral collapse or moral decline (Turmidzi, 2021). Therefore, the Government was currently promoting character education in schools with various programs. The need for character education was urgent to be carried out because of the symptoms that indicated the destruction of the nation's character.

Through the Ministry of National Education, the government had launched the implementation of character education for all levels of education from elementary to university. The emergence of character education programs in the world of education in Indonesia was understandable because so far, it was felt that the education process had not succeeded in building Indonesian people with character. Many said that education had failed to build character. Many school graduates and scholars were good at answering exam questions, having intelligent minds, but were mentally weak, cowardly and their behaviour was not commendable. However, character education that was applied did not necessarily reveal the form/result but was a long process (Dalyono \& Lestariningsih, 2016). The Ministry and stakeholders, one of which was educational institutions, welcomed this desire to be implemented in schools.

Educational institutions hold the main key to teaching the character and morals of students. They were taught manners, honesty, responsibility, integrity, discipline, hard work, and solidarity. We hoped that schools and madrasas would become laboratories of character and morals apart from being the crater of the candradimuka for future leaders of the Indonesian nation and state (Dalyono \& Lestariningsih, 2016). In addition, parents play an important role in developing their children's potential. Parents were the first and foremost educators in the family environment. Parents needed to be aware that children had great potential at birth (Widianto, 2015). Therefore, the role of parents and schools was very important in an effort to prevent teenagers from doing bad things. Because preventing the occurrence of moral decadence can be started in the family environment. After that, the school as a formal institution played a role in continuing and strengthening these efforts.

Some of the efforts of educational institutions to prevent moral decadence in adolescents included Islamic Religious Education (Azizah, 2016; Marwah, 2019), optimizing the role of teachers (Afif, 2021; Fitri, 2020; Muttaqin et al., 2021; Sapudini, 2018), group guidance services (Rahmawati et al., 2017), recitation (Jamal, 2016), Living Values Education (LVE) approach (Herlambang, 2021), and other research. To prevent moral decadence in adolescents, it was necessary to foster student diversity. Religion had a very important role because the moral values that came from religion remain unchanged due to changes in time and place. 
Therefore, religious guidance in schools was very important for teenagers to save them from delinquency and was a way to prepare for future generations because mistakes in moral development will negatively impact the youth themselves. Understanding of religion should be done since childhood, namely through both parents by providing moral guidance and religious guidance because religious guidance was the main element of power to ward off negative consequences in people's lives (Mauzu, 2021). Religious development was one of the efforts to ward off negative influences. Therefore, schools and parents needed to work together to instil religious education in order to differentiate between good and bad deeds.

\section{METHOD}

The research method was descriptive qualitative research with a phenomenological approach. The object of this research is the teacher and their activities, programs, and extracurricular activities at MA Patra Mandiri Palembang. The informants in the study were the principal, vice-principal for student affairs, four subject teachers, and four teachers who were supervisors of religious extracurricular activities. Data were collected through observation with active participation observation techniques, namely the researcher was involved with the activities that became the focus of the research. What the researchers did was to observe and record the implementation of extracurricular programs and activities. In contrast, in in-depth interviews with unstructured interview techniques, each respondent was given questions that were not necessarily the same, and data collectors recorded them. The final stage was that the data were analyzed in three steps, namely 1) data reduction by summarizing, selecting the main things, focusing on the important things, looking for themes and patterns, and discarding unnecessary ones. So that it will provide a clearer picture and make it easier for the researcher to do the next data collection and look for it again when needed; 2) data presentation by parsing research results in the form of graphs, matrices, and others; and 3) concluding by member check and triangulation.

\section{FINDINGS AND DISCUSSION}

The religious guidance of students can be done in various ways, one of which was done by this madrasa by exemplary teachers, religious programs, and religious extracurricular activities. This was done to prevent students from the negative influence of globalization which can damage students' morals.

\section{Exemplary Teacher}

Guidance by exemplary meant guiding by giving an example, both in behavior, attitudes, ways of thinking, and so on. Exemplary was one part of the most effective and powerful learning method in shaping students' character, including religious characters. Because through this example, students directly saw the ideal figure in the child's view, whose behaviour, words, and actions will be imitated.

The exemplary teacher had a substantial contribution in shaping the attitudes or behavior of students. The exemplary teacher in his various activities will be a mirror for his students. Therefore, the figure of a teacher who can be imitated by students had a very important position. Teachers who are accustomed to discipline, friendly and moral, will be a good example for their students, as well as preferably.

In this case, Mrs. AO explained as followed:

"... one of the ways that I did in guiding and fostering student religion was through positive examples of attitudes and actions related to character, for example being friendly and polite with fellow teachers and peers, not participating in imitating negative behavior that was not suitable with religious teachings."

The following was also conveyed by Mr. SU:

"... I got students used to taking part in activities that discussed and explored religious knowledge, such as recitation activities, tahsin, and others. From these 
activities, I gave an example by guiding and directing students about a character based on Islamic teachings that they saw directly."

Likewise, the following was conveyed by Ms. DA:

“... to be a good example in realizing the character of students, I did this by guiding and getting used to behaving according to Islamic teachings, speaking in a friendly, gentle, and polite manner. Because of these things, if you get used to it will be the main factor in shaping the character of students. The crisis of exemplary from the environment can lead to bad behavior."

Furthermore, Mr DI conveyed the following:

“... as a teacher, I tried to give good examples of attitudes and behavior in daily life that were in accordance with religious teachings to guide and shape the character of students. I tried to do things that are trivial and I did. Of course these will be the examples or role models for students, therefore I believed that creating students with positive characteristics must be done first and cannot be explained only."

Likewise, Mr. K conveyed the following:

"... I showed character values that were in accordance with the teachings of Islam which I did through actions, where all my actions must be in accordance with religious teachings, my actions showed actions that were permitted by religion, the attitude of speaking and acting was also based on religious teachings, so that Thus students saw for themselves examples that were really real and in accordance with the teachings of Islam. I give examples to other students such as reading the Qur'an, reciting the Qur'an, sunnah prayers, and mandatory prayers that were held at school."

Furthermore, the head of the madrasa, Mr. AK, said as followed:

“... exemplary was very important for teachers, because exemplary was a very influential method for students. Students will easily imitate their teachers in various ways, because the characteristics of students were great imitators. For this reason, a teacher must have noble character so that he/she can be an example for his students. So that the ancients said "the teacher is a person who is always trusted and imitated". There were many activities that can be imitated by such as studying religious knowledge, reading the Qur'an, reciting the Qur'an, praying Duha, and praying Zuhur."

Based on the results of observations done, it was seen that they did guidance, gave advice, and guided religious students through exemplary attitudes and behavior that showed character values that were by Islamic teachings. In guiding student religion, the teacher displayed commendable morals such as speaking politely. Furthermore, the teacher did religious teachings such as reading the Qur'an both in the teacher's room and mosque, attending the recitation, doing the Duha prayer, Zuhur and Friday prayers, reading Salawat, and other activities.

The strategic role of the teachers in all aspects made the teachers the most beautiful exemplary for their students. So there was no opportunity for teachers to hide from the sight of their students. All teacher behavior, from intentional to unintentional, close to far, from personal and professional, speech, behavior, thoughts, and ways of expressing emotions, all and everything gave an aura to the lives of their students.

The teacher was trusted and imitated; this expression was a must even though its implementation was not easy. The madrasa, especially the principal, asked all school members, especially teachers, to be role models in applying character education. As an exemplary figure, the teacher must have a good personality related to the personality and moral competence of the teacher. Personal competence in question was a personal ability that reflected the personality, while the moral in question was commendable behavior. 
All teachers at this madrasa were committed to displaying personalities and morals that should be imitated by students when communicating, interacting, and being competent both inside and outside school. When communicating using a soft voice and speaking honestly, friendly, sincere, helpful, and other commendable morals. Teachers as parents of both students at school must be moral as the main basis in learning.

Teachers were expected to do religious teachings as much as possible in the form of worship and morals that were sourced from the Qur'an and Hadith while at school or outside of school. Some of the worship that teachers can do such as reading Al-Qur'an, Duha prayer, Zuhur prayer, Asr prayer, and other worship. Not only that, the teacher displayed commendable morals while interacting and communicating, such as saying good, honest, disciplined, responsible, and other commendable morals. Moreover, if religious activities done by teachers involved students, of course, this will be more effective in efforts to guide student religiosity. This was what the school did in guiding student diversity through the example of teachers.

The exemplary teachers played a very important and influential role in guiding student diversity. While at school, the teachers must be good at maintaining an attitude to give the best example, teach moral values in lessons, be honest to themselves and open to mistakes, do obligations with full responsibility and high awareness, be polite and so on.

Thus, students' attitude at school cannot be separated from the role of the teacher, because what students did will return to what was shown by the teacher. Aren't students a reflection of the teacher, children were a reflection of their parents, and the people were a reflection of their leaders. So there was reciprocal interaction between teachers and students. So that in the end, student learning outcomes will determine whether after students take part in learning, it will change for the better or vice versa, even knowledge, skills, or student attitudes (Amelia, 2021).

The results of the study supported previous research that the exemplary teacher was an alternative in guiding student religion, including Asmuni's research (2021) that the example shown by the teacher in guiding students' religious attitudes was through piety, noble character, honesty, discipline, fairness and objectivity done inside and outside the classroom and also in religious activities in the madrasa. Siti's research (2017) that teachers must always give a good example to their students, both by implementing Islamic teachings in class and religious guidance through Imtak (faith and piety) activities that were done every day at school.

Furthermore, Amelia's research (2021) found that all teachers who taught in schools directly gave examples to students in the form of doing Allah's commands, sunnah fasting, weekly donations, Duha prayer, reading the Qur'an, being honest, polite, respecting fellow responsibilities, disciplined, honest, doing the duties and respecting for the teacher to describe his religious attitude.

\section{Religious Programs}

Religious guidance of Students was done by doing religious teachings that Allah SWT had ordered. Habituation must be done continuously in an effort to guide student religion. In this Mr YC stated the following:

"... the school was trying to guider the religion of students by doing religious teachings, both mandatory and sunnah. Every day all students were required to pray Zuhur in congregation in the mosque, on Friday for male students were required to perform Friday prayers in the congregation, and every day students were reminded to do the Duha sunnah prayer."

Furthermore, Mr. AK stated as follows:

"... the school had a strategy in guiding student diversity, one of which was by doing worship at school. With this worship, good character will be formed in students. Therefore, every day students were asked to pray 5 times a day such as Zuhur at school, Friday prayers, attending recitations during the month of Ramadan, and other worship." 
Based on the observations made, it was seen that students and teachers did several religious services, especially obligatory worship such as the Zuhur prayer. During the Zuhur prayer time, all students left the classroom to the mosque held every day. It was also seen that some students performed the Duha prayer at the mosque in the morning.

Thus, the religious guidance of students was done with several religious programs including:

a. Duha prayer. Duha prayer was a sunnah prayer that students and teachers routinely did. However, this program was not a necessity but a recommendation because of the virtue of this prayer. Despite the recommendation, many students and teachers did it both in the congregation and alone (munfarid).

b. Zuhr prayer. This program was mandatory for all students when entering the Zuhur prayer time. This prayer was done in congregation with students and teachers.

c. Friday prayer. This program was mandatory for male students and teachers only. Friday's officers collaborated between teachers and students, such as Adzan and bilal by students, khotbah, and imam by the teacher.

d. Ramadan Islamic Boarding School. This program was done in order to revitalize the holy month with several activities, including religious speech. This activity was a collaboration between intra-school student organization administrators and teachers.

The religious program at this school was one of the efforts to internalize religious values into students. This was the function of the school, namely as an institution that functioned to transmit culture (Latif, 2005). The school was a place for internalizing religious culture to students so that students had a strong fortress to form a noble character. Meanwhile, the noble character was the basic foundation for improving this declining human resource (Jamil, 2017).

Several studies had shown that due to the implementation of religious programs, it had been proven that there was an achievement of disciplinary character (Jamil, 2017; Rodiyah, 2020; Wandi, 2020), religious character (Nugroho, 2019; Pohan, 2019), social character (Yunika, 2021). Even other research proved that religious programs significantly influenced students' morals (Febriyani \& Sunarto, 2021).

The religious program above did more prayers. Prayer was a command of Allah, so the reflection of a Muslim was to do Allah's commands and stay away from His prohibitions. Prayer was proven to effectively prevent someone from doing vile and evil acts, as Allah said in Surah al-Ankabut verse 45. In addition, prayer was effective in shaping one's character, as researched by Amalia (2021) and Saryadi (2020).

\section{Religious Extracurricular}

Religious extracurricular was one of the important elements in building students' personality. The goal was to instill religious teachings so that they became religious and had noble character. It also aimed to motivate and explore the potential of students in the field of religion. Mr. AK as the principal, stated as follows:

"... the goal of Religious Extracurricular was to familiarize students with noble character, guiding diversity, and getting used to living in society. We were aware that it was not enough to just rely on the material in class. Therefore, we guided them through several programs in Religious Extracurricular."

To achieve this goal, Mr. AK explained that:

“... in order to realize these goals, madrasas added activities in the Religious Extracurricular, namely 1) Morning greetings; 2) Duha prayer; 3) Friday prayers for male students; 4) Zuhur prayer together; 5) Tahsinul Qur'an; 6) Marhaba; 7) Barzanji; and 8) Muhadhoroh."

The programs in the Religious Extracurricular above had their own goals. As explained by Mr. $\mathrm{K}$ as the supervisor of the activities as follows: 
“... Muhadhoroh's activities aimed to give religious knowledge to students through religious speech and at the same time train students to become members of the community such as giving a religious speech at certain events, being $M C$, giving speeches, and leading prayers."

“... the Barzanji activity aimed to train students'skills in reading Barzanji as was often held in the community and to instil a sense of love for the Prophet Muhammad through reading his life history".

Mr SU, as the supervisor of the Tahsinul Qur'an activity, explained the goals as followed:

“... Tahsinul Qur'an aimed to familiarize students with reading the Qur'an properly and correctly. In this activity, students were guided together to read the Qur'an including the law of tajwid."

Furthermore, Mr AK as the supervisor of Marhaba activities, explained the goals as follows:

“... Marhaba activities aimed to train students' skills in reading Marhaba with the rhythm of the song while praising the Prophet Muhammad through the poems contained in Marhaba."

Religious extracurricular was one of the school's strategies and efforts to give reinforcement of the materials in intra-curricular subjects and religious programs. Here were some of the activities including:

a. Tahsinul Qur'an

This activity was a program to improve and beautify the reading of the Qur'an which was done every Tuesday in the morning. This program was guided directly by religious teachers. Beginning with the teacher reading a few verses of the Qur'an then followed by all students. The number of verses reads was 5 to 7 verses. After that, the teacher explained the content of the verses read.

b. Marhaba.

This activity contained the reading of historical poems of the Prophet Muhammad which was listed in the Barzanji book by Sheikh Ja'far bin Hasan with the rhythm of the song. This activity was done every Wednesday morning under the guidance of the school principal and religious teachers. The participants in this activity were students in classes that had been scheduled by the administrators of the intra-school student organization.

c. Barzanji

This activity contained the reading of historical poems of the Prophet Muhammad which was listed in the Barzanji book by Sheikh Ja'far bin Hasan without the rhythm of the song. This activity was done every Thursday morning under the guidance of the school principal and religious teachers. The participants in this activity were students in classes that had been scheduled by the administrators of the intra-school student organization.

d. Muhadhoroh.

This activity was an activity to train students' public speaking skills such as being an emcee (MC), reading recitations, reading prayers, and giving speeches which were held every Friday. The participants in this activity were students in classes that have been scheduled by the administrators of the intra-school student organization.

e. Hadrah. This activity was one of the Islamic arts accompanied by a tambourine.

Religious extracurricular programs were various program activities that were held outside of class hours in order to give direction for students to be able to practice the religious teachings obtained through classroom learning activities as well as to encourage the personal formation of students and the cultivation of religious values and commendable morals of students. The goal was to form educated and devoted human beings to Allah SWT (Indonesia, 2005).

The existence of extracurricular activities was considered important, considering that its contribution to students' strengthening and character building was very large. As was known today, 
so many incidents of juvenile delinquency took place. Various negative or deviant actions were done by some teenagers, which seemed to be thought by teenagers to be just mediocre. Moreover, some considered it something to be proud of (Hanifah et al., 2021; Kurniawan, 2013).

At present, schools did not only rely on religious lessons in classes that had little time but added religious programs to extra hours outside of class and even made extracurricular activities. There have been many schools that used extracurricular activities in guiding student diversity to fortify themselves from the negative effects of globalization. Religious extracurricular activities were very important in value education because, in these activities, students got direct experience, were actively involved, and were given enough time outside the effective hours of lessons, so that value education was more accommodated through extracurricular activities (Supiani et al., 2020).

Hambali (2018) stated that the implementation of religious extracurricular on the formation of students' religious character had a very large influence. It had a positive impact in helping students be younger in living Islamic religious values and helping to suppress juvenile delinquency and bad influences on students. This finding was strengthened by Rijal's research (2019) ) that religious guidance impacted increasing students' religious attitudes and madrasa development, both in quality and quantity. Furthermore, the implementation of religious extracurricular impacted changes for the better, one of which was a change in attitude (Kholisotin \& Minarsih, 2018).

\section{CONCLUSION}

The study concluded that efforts to prevent moral decadence in adolescents were done by guiding student diversity through three strategies, namely exemplary teacher; religious programs such as Duha prayers, Zuhur prayers, Friday prayers, and Ramadan Islamic Boarding Schools; and religious extracurricular such as Tahsinul Qur'an, Barzanji, Marhaba, Muhadharah, and hadrah. The research implied that schools needed to optimize religious extracurricular programs and activities so that they became the school flagship program and guide student religion. As for suggestions for further research, it was necessary to do how exemplary teachers, religious programs, and extracurricular activities influence student diversity quantitatively.

\section{REFERENCES}

Afif, M. (2021). PERAN PENDIDIK DALAM MENGATASI DEKADENSI MORAL DI SMP AN-NUR. $A L-A L L A M, 2(1), 27-39$.

Amalia, C. N. (2021). Pengaruh Pembiasaan Shalat Dhuha Terhadap Karakter Siswa-Siswi MAN 1 Kabupaten Bogor. Jurnal Inspiratif Pendidikan, 10(1), 165-172.

Amelia, J. (2021). Peran Keteladanan Guru Pai Dalam Pembentukan Karakter Religius Siswa SMP Negeri o7 Lubuk Linggau. UIN Fatmawati Sukarno.

Asmuni, A. (2021). Pembinaan Sikap Keagamaan Melaui Keteladanan Guru Dan Budaya Sekolah Siswa MTs Prakarya PUI Panjalin Kabupaten Majalengka: Dirmanto, Ahmad Asmuni, dan Suteja. My Campaign Journal, 2(04).

Azizah, S. N. (2016). Pendidikan Agama Islam sebagai Upaya Preventif dalam Mengatasi Dekadensi Moral Remaja di MAN Tlogo Blitar.

Budiningsih, C. A. (2004). Pembelajaran Moral. Rineka Cipta.

Dalyono, B., \& Lestariningsih, E. D. (2016). Implementasi Penguatan Pendidikan Karakter Di Sekolah. Bangun Rekaprima: Majalah Ilmiah Pengembangan Rekayasa, Sosial Dan Humaniora, 3(2, Oktober), 33-42.

Daradjat, Z. (2000). Ilmu Pendidikan Islam. Bumi Aksara.

Febriyani, A. R., \& Sunarto, S. (2021). Pengaruh 4 Program Keagamaan Terhadap Akhlak Peserta Didik Di SMP Muhammadiyah 8 Batu. Al-Tadzkiyyah: Jurnal Pendidikan Islam, 12(1), 85-93.

Fitri, M. S. (2020). Peran Guru PAI Dalam Mengatasi Kenakalan Remaja (Studi Kasus Di MA Nurul Mujtahidin Mlarak Tahun Pelajaran 2019/2020). IAIN Ponorogo. 
Hambali, M., \& Yulianti, E. (2018). Ekstrakurikuler keagamaan terhadap pembentukan karakter religius peserta didik di kota majapahit. PEDAGOGIK: Jurnal Pendidikan, 5(2), 193-208.

Hanifah, F. M., Fiyul, A. Y., \& Ginanjar, W. (2021). Pembentukan Karakter Siswa Melalui Kegiatan Ekstrakurikuler Keagamaan di SMP Islam Terpadu Insan Mandiri Kota Sukabumi. Jurnal'Ulumuddin, 3(1), 65-89.

Herlambang, Y. T. (2021). Menanggulangi Dekadensi Moral Generasi Z Akibat Media Sosial Melalui Pendekatan Living Values Education (LVE). PEMBELAJAR: Jurnal Ilmu Pendidikan, Keguruan, Dan Pembelajaran, 5(2), 150-158.

Indonesia, P. (2005). Panduan Kegiatan Ekstrakurikuler Pendidikan Agama Islam. Direktorat Jenderal Kelembagaan Agama Islam Departemen Agama Republik Indonesia.

Jamal, N. (2016). Pengajian dan Dekadensi Moral Remaja. KABILAH: Journal of Social Community, 1(1), 170-197.

Jamil, A. (2017). Implementasi program keagamaan dalam membentuk nilai karakter disiplin pada siswa di MTSN Lawang Kabupaten Malang. Universitas Islam Negeri Maulana Malik Ibrahim.

Jannah, M. (2021). Upaya Masyarakat dalam Mengatasi Dekadensi Moral Remaja di Gampong Beunot, Syamtalira Bayu, Aceh Utara. Tadabbur: Jurnal Peradaban Islam, 3(2), 347-357.

Kholisotin, L., \& Minarsih, M. (2018). Implementasi Ekstrakurikuler Keagamaan di SMKN-1 Palangka Raya. Anterior Jurnal, 18(1), 71-78.

Kurniawan, A. (2013). Penanaman Nilai-nilai Tasawuf dalam Rangka Pembinaan Akhlak di Sekiolah Melalui Kegiatan Ekstrakurikuler Keagamaan. Al-Tahrir: Jurnal Pemikiran Islam, 13(1), 187206.

Latif, A. (2005). Pendidikan Berbasis Nilai Kemasyarakatan. Refika Aditama.

Marwah, Z. (2019). Peranan pendidikan agama islam dalam mengatasi dekadensi moral (studi kasus desa melati II kec. perbaungan kab. deli serdang). JURNAL ILMIAH SOSIOLOGI AGAMA (JISA), 2(2), 117-137.

Mauzu, F. (2021). Kenakalan Remaja dan Penanganannya. JPIn: Jurnal Pendidik Indonesia, 4(1), $171-184$.

Megawangi, R. (2004). Pendidikan Karakter. Indonesia Heritage Foundation.

Muttaqin, I., Sa'dijah, C., \& Safi'i, I. (2021). Kinerja Guru Pai Dalam Mengatasi Kenakalan Remaja Di Sekolah Menengah Pertama PGRI Pujon. Vicratina: Jurnal Pendidikan Islam, 6(4), 141151.

Nugroho, M. (2019). Implementasi program keagamaan sebagai upaya pembentukan karakter religius siswa di Ma'had Raudhotul Ulum Madrasah Tsanawiyah Negeri (MTsN) 2 Kediri. Universitas Islam Negeri Maulana Malik Ibrahim.

Nurbayan, S. (2017). Upaya guru Pendidikan Agama Islam dalam membina sikap keagamaan Siswa di kelas VIII A SMP Negeri 2 Labuapi tahun pelajaran 2016/2017. UIN Mataram.

Pohan, A. S. (2019). Internalisasi nilai-nilai religius dan kedisiplinan mahasantri melalui program keagamaan di lembaga Ma’had Sunan Ampel Al-Aly UIN Maulana Malik Ibrahim Malang. Universitas Islam Negeri Maulana Malik Ibrahim.

Rahmawati, N. K. D., Mardiyah, R. R., \& Wardani, S. Y. (2017). Layanan Bimbingan Kelompok untuk Mencegah Degradasi Moral Remaja. Prosiding Seminar Nasional Bimbingan Dan Konseling, 1(1), 134-144.

Rijal, S. (2019). Pembinaan Keagamaan Peserta Didik Melalui Kegiatan Ekstrakulikuler Di Madrasah Ibtidaiyyah As'adiyah Banua Baru. Jurnal Inspiratif Pendidikan, 8(1), 114-125.

Rodiyah, A. (2020). Implementasi Program Keagamaan dalam Membentuk Nilai Karater Disiplin pada Siswa di SMP Islam Wajak Kabupaten Malang .

SAPUDINI, D. (2018). Peran Guru Pendidikan Agama Islam Dalam Mengatasi Dekadensi Moral Siswa (Studi di SMPN 13 Kota Serang). Universitas Islam Negeri" Sultan Maulana 
Hasanuddin" Banten.

Sarwono, S. W. (1997). Psikologi Remaja. Raja Grafindo Persada.

Saryadi, S., Putri, S. N. A., Puspitasari, H., \& Setyaningsih, E. (2020). Pembiasaan Sholat Dhuha Berjama'ah Terhadap Pendidikan Karakter Siswa Di Smp Muhammadiyah 4 SAMBI. Buletin Literasi Budaya Sekolah, 2(2), 120-125.

Supiani, S., Muryati, D., \& Saefulloh, A. (2020). Pelaksanaan Kegiatan Ekstrakurikuler Keagamaan Di Man Kota Palangkaraya Secara Daring. ENGGANG: Jurnal Pendidikan, Bahasa, Sastra, Seni, Dan Budaya, 1(1), 30-39.

Tashandra, N. (2021). Pandemi Covid-19, Mengapa Kenakalan Remaja Masih Banyak Terjadi? Kompas.Com. https://lifestyle.kompas.com/read/2021/o7/23/102710420/pandemi-covid19-mengapa-kenakalan-remaja-masih-banyak-terjadi?page=all

Turmidzi, I. (2021). Pengelolaan Pendidikan Bermutu Di Madrasah. Tarbawi: Jurnal Pemikiran Dan Pendidikan Islam, 4(2), 165-181.

Wandi, A. (2020). Implementasi Program Keagamaan dalam Membentuk Karakter Disiplin Peserta Didik di SDIT Istiqomah Lembang. TARBAWI: Jurnal Pendidikan Agama Islam, 5(02), 104114 .

Widianto, E. (2015). Peran Orangtua Dalam Meningkatkan Pendidikan Karakter Anak Usia Dini Dalam Keluarga. Jurnal PG-PAUD Trunojoyo: Jurnal Pendidikan Dan Pembelajaran Anak Usia Dini, 2(1), 31-39.

Yunika, T. M. (2021). Hubungan Program-Program Keagamaan dengan Karakter Sosial Siswa di SMPN 1 Tenjo Kabupaten Bogor Provinsi Jawa Barat. UIN SMH BANTEN. 